The prothrombotic effects of female sex steroids are well known, and it has been suggested that the oral contraceptives may be implicated in the development of primary pulmonary hypertension as a result of increased tendency to thrombosis or a direct proliferative effect on the intima of the pulmonary arteries. $^{7}$ There are case reports of severe deterioration in patients with established pulmonary vascular disease coinciding with the introduction of pills containing oestrogen, ${ }^{8}$ and of patients presenting with primary pulmonary hypertension soon after starting such treatment. ${ }^{9}$ However, data from the National Heart, Lung and Blood Institute primary pulmonary hypertension registryshow no difference in the frequency of use of oral contraceptives in 194 registered patients and the general population. ${ }^{10}$

The link between oestrogens and primary pulmonary hypertension is one of the issues specifically addressed in the International Primary Pulmonary Hypertension Study, which has recently reported its findings. ${ }^{11}$ This case-control study of 95 prospectively enrolled patients presenting with primary pulmonary hypertension found no difference in the frequency of use of oral contraceptives between patients and controls, while confirming the increased risk associated with the use of some appetite suppressants, intravenous drug misuse, and HIV infection.

There are two established medical treatments that have been shown to be effective in improving the clinical condition, and to a limited extent prognosis, of patients in addition to anticoagulation. On haemodynamic testing, about a quarter of patients show a significant reduction in pulmonary artery pressure and pulmonary vascular resistance with high doses of calcium antagonists. These patients derive long term benefit from long term treatment. ${ }^{12}$ The doses required are high (for example, nifedipine $240 \mathrm{mg} /$ day), and there is a danger of exacerbating right ventricular dysfunction and causing haemodynamic collapse in patients who have little pulmonary vasoreactivity. Use of this treatment has been limited by the need for patients to have appropriate haemodynamic characteristics and to be able to tolerate the side effects. Prostacyclin is a potent pulmonary vasodilator in responsive patients, and its antithrombotic action is also of potential benefit. Its short half life means that long term treatment must be by continuous infusion, and this technique has been associated with an improvement in patients with advanced disease and sometimes little apparent vasoreactivity. ${ }^{13}$ The problems of continuous infusion limit its application to patients with severe disease, usually as a bridge to transplantation.

Transplantation at present offers the best chance of long term survival. Heart-lung, single lung, and double lung transplants are established techniques with reasonable success in patients who are hypoxic and have evidence of severe right ventricular dysfunction. It is increasingly apparent that right ventricular failure may be reversible with the reduction in afterload that occurs after lung transplantation, and single lung transplantation increases the potential number of patients who can benefit from the limited supply of donor organs.

Possible new palliative treatments include oral prostaglandin preparations and endothelin inhibitors, inhaled nitric oxide or intravenous nitric oxide precursors, and perhaps atrial septostomy in patients with advanced right ventricular dysfunction. However, since established vascular disease is present in most cases at presentation, early recognition and prevention of progression will be the keys to substantially altering the natural course of this condition.

In conditions that predispose to pulmonary hypertension, such as systemic sclerosis or atrial septal defect, and in patients with established primary or secondary pulmonary vascular disease, there is no doubt that pregnancy is associated with clinical deterioration and high mortality. In such cases there is probably a substantial risk associated with using oral contraceptives, particularly oestrogen containing preparations. However, in other women, apart from those from rare families in which the disease seems to have a direct mendelian inheritance, the risk of primary pulmonary hypertension does not warrant refusal to provide routine oral contraception.

ANDREW BISHOP Senior registrar

Cardiac Department,

St Thomas's Hospital,

London SE1 7EH

PAUL OLDERSHAW

Consultant cardiologist

Royal Brompton Hospital,

London SW3 6NP

1 Wood P. Pulmonary hypertension. Br Med Bull 1952;8:348-53.

2 Christmas BW, McPherson. CD, Newman JH, King GA, Bernard GR, Groves BM, et al. An imbalance between the excretion of thromboxane and prostacyclin metabolites in pulmonary hypertension. N Engl f Med 1992;327:70-5.

3 Worsley DF, Palcvsky HI, Alavi A. Ventilation-perfusion scanning in the evaluation of pulmonary hypertension. \% Nuc Med 1994;35:793-6.

4 Wagenvoort CA, Mulder P. Thrombotic lesions in primary plexogenic arteriopathy. Chest 1993;103:844-9.

5 Moser KM, Fedullo PF, Finkbeiner WE, Golden J. Do patients with primary pulmonary hypertension develop extensive central thrombi? Circ 1995;91:741-5.

6 Fuster V, Steele P, Edwards W, Gersh B, McGoon M, Frye R. Primary pulmonary hypertension: natural history and the importance of thrombosis. Circulation 1984;70:580-7. 7 Irey N, Norris N. Intimal vascular lesions associated with female reproductive steroids. Arch Pathol 1973;96:227-34.

8 Oakley C, Somerville J. Oral contraceptives and progressive pulmonary vascular disease. Lancet $1968 ; 1: 890-3$.

9 Kleiger E, Boxer M, Ingham E, Harrison D. Pulmonary hypertension in patients using oral contraceptives. Chest 1976;69:143-7.

10 D'Alonzo G, Barst R, Ayres S, Brundage B, Detre K. Survival in patients with primary pulmonary hypertension. Ann Intern Med 1987;107:216-23.

11 Abenhaim F, Moride Y, Rich S, Benicho J, Kurz X, et al. Appetite suppressant drugs and risk of primary pulmonary hypertension. N Engl I Med 1996;609:16.

2 Rich S, Kaufmann E, Levey P. The effect of high doses of calcium channel blockers on survival ich S, Kaufmann E, Levey P. The effect of high doses of calcium chan
in primary pulmonary hypertension. $N$ Engl I Med 1992;327:76-81.

13 Higenbottam $T$, Wheeldon $D$, Wells $F$, Wallwork J. Long term treatment of primary pulmonary hypertension with intravenous eprostanol (prostacyclin). Lancet 1984;1:1046-7.

\title{
Heart attacks and homocysteine
}

\section{Time for a randomised controlled trial of plasma homocysteine reduction}

It is now accepted that an elevated plasma concentration of homocysteine is a risk factor for atherosclerotic vascular disease affecting the coronary, cerebral, and peripheral arteries. ${ }^{1}$ Prospective data ${ }^{2-4}$ confirm the findings of casecontrol studies ${ }^{5-8}$ and indicate that an elevated plasma homocysteine concentration precedes the development of disease and that there is a dose-response effect.
A $5 \mu \mathrm{mol} / 1$ increase in plasma homocysteine concentration has been estimated to raise the risk of coronary heart disease by as much as an increase in serum cholesterol concentration of $0.5 \mathrm{mmol} / 1 .{ }^{1}$ Data from the European Union concerted action project, a case-control study of 750 patients with vascular disease and 800 controls, indicate that a plasma homocysteine concentration above $12 \mu \mathrm{mol} / 1$ (the top fifth of 
the control distribution) doubles the risk of myocardial infarction and cerebral or peripheral vascular disease in both men and women. ${ }^{9}$ Additional patients at high risk can be identified by stressing the methionine pathway by means of a methionine loading test, analogous to a glucose tolerance test. Both genetic and nutritional factors influence homocysteine concentrations; since simple nutrient supplementation with folic acid can reduce homocysteine concentrations in almost all subjects, these observations may have substantial public health implications.

Homocysteine is a sulphur amino acid produced by demethylation of the essential amino acid methionine. It may be irreversibly degraded by cystathionine $\beta$-synthase. This enzyme requires vitamin $\mathrm{B} 6$ as a cofactor. Alternatively, homocysteine may be remethylated to conserve methionine, a process requiring several enzymes. Of these, methionine synthase requires methylcobalamin as a cofactor and methyltetrahydrofolate as a co-substrate. Production of methyltetrahydrofolate requires both an adequate supply of folate and the enzyme methylene tetrahydrofolate reductase. Dysfunctional enzymes or inadequate amounts of nutrients may therefore lead to an elevated concentration of intracellular homocysteine, which is then exported to the plasma.

Homocystinuria occurs when plasma homocysteine concentrations are sufficiently high to be excreted in the urine as the disulphide homocystine. Classically, it is caused by homozygous deficiency of cystathionine $\beta$-synthase. ${ }^{10}$ Rarer causes are homozygous deficiency in methylene tetrahydrofolate reductase and defects in cobalamin metabolism. The observation that such distinct conditions share both an elevated plasma homocysteine concentration and the development of precocious vascular disease led McCully to formulate the homocysteine theory of atherosclerosis. ${ }^{11} \mathrm{~A}$ commoner genetic defect is the presence of the thermolabile variant of methylene tetrahydrofolate reductase, which reduces but does not abolish enzyme activity. This mutation occurs in perhaps $5-7 \%$ of normal subjects and is associated with increased risk of vascular disease in some studies, ${ }^{12}{ }^{13}$ though not all. ${ }^{14}{ }^{15}$

Deficiency of the nutrients which regulate homocysteine metabolism may be a more common cause of mildly raised plasma homocysteine concentrations than genetic defects, ${ }^{16}$ although interaction effects seem likely. ${ }^{17}$ Concentrations of both folate and vitamin B12 relate inversely to plasma homocysteine ${ }^{18}$ and a raised plasma homocysteine concentration is a sensitive marker for even low normal intakes of folate and vitamin B12. ${ }^{19}$ It follows that current reference ranges for plasma nutrient concentrations and recommended daily intakes may need revision.

Despite sound epidemiological evidence for a strong, graded, and independent relation between homocysteine and coronary heart disease, the mechanism of how homocysteine may be atherogenic remains unclear. Experimental evidence of the capacity of homocysteine to damage vascular endothelium; to interact with platelets, low density lipoprotein cholesterol, and clotting factors; and to impair nitric oxide function has been reported. ${ }^{20}$ Many such experiments have used species of homocysteine not prevalent in vivo and at artificially high concentrations. Many require replication and extension.

The demonstration that a raised plasma homocysteine concentration is a powerful risk factor for vascular disease is of little value unless homocysteine concentration can be reduced and there is a resulting reduction in risk. Only then can the relation be judged to be causal beyond reasonable doubt. Dietary supplementation with folic acid reduces plasma homocysteine concentrations by about $30 \%$ in almost all subjects. The effect of vitamin B12 is modest, except in deficient subjects. Vitamin B6 has more effect on lowering homocysteine concentrations unmasked by methionine loading than on basal concentrations, but the clinical importance of this observation is uncertain. A meta-analysis of dose finding studies, particularly with regard to folic acid, is under way. The optimal dose is uncertain but may be around $1 \mathrm{mg}$.

Since homocysteine is unequivocally linked with vascular disease and since plasma homocysteine concentration can be reduced simply and cheaply with folic acid, it is now a matter of urgency to ascertain whether reducing plasma homocysteine concentration reduces coronary risk. Estimates of the effect of folate supplementation or food fortification on the risk of coronary heart disease have been reported, but hard evidence of benefit accruing from reducing plasma homocysteine concentration is not yet available. Were folic acid a patentable new product, it is likely that such trials would already be under way. As it is, the most likely next step will be the addition of a homocysteine lowering component to one of the large secondary prevention trials of lipid or blood pressure treatment currently being planned. Only when the results of such trials are available will it be possible to decide whether homocysteine deserves its place as a major causal risk factor for coronary disease.

IAN GRAHAM

Professor of epidemiology and preventive medicine

Royal College of Surgeons in Ireland,

Dublin 2,

Ireland

RAYMOND MELEADY

Research fellow

Adelaide Hospital,

Dublin 8,

Ireland

1 Boushey C, Beresford SAA, Omenn G, Motulsky A. A quantitative assessment of plasm homocysteine as a risk factor for vascular disease. Probable benefits of increasing folic acid intakes. FAMA 1995;274:1049-57.

2 Stampfer MJ, Malinow R, Willet WC, Newcomer L, Upson B, Ullman D, et al. A prospective study of plasma homocyst(e)ine and risk of myocardial infarction in US physicians. $\Im A M A$ 1992;268:877-81.

3 Perry IJ, Refsum H, Morris RW, Ebrahim SB, Ueland PM, Shaper AG. Prospective study of serum total homocysteine concentration and risk of stroke in middle-aged British men. Lan cet 1995;346:1395-8.

4 Arnesen E, Refsum H, Bonaa KH, Ueland PM, Forde OH, Nordrehaug JE. Serum total homocysteine and coronary heart disease. Int $f$ Epidemiol 1995;24:704-9.

5 Clarke R, Daly L, Robinson K, Naughten E, Cahalane S, Fowler B, et al. Hyperhomocysteinemia: an independent risk factor for vascular disease. N Engl f Med 1991;324:1149-55.

6 Pancharuniti N, Lewis CA, Sauberlich HE, Perkins LL, Go RCP, Alvarez J, et al. Plasma homocyst(e)ine, folate, and vitamin $B 12$ concentrations and risk for early-onset coronary artery cyst(e)ine, folate, and vitamin B12 concer

7 Robinson K, Mayer EL, Miller DP, Green R, van Lente F, Gupta A, et al. Hyperhomocysteinemia and low pyridoxal phosphate; common and independent risk factors for coronary artery disease. Circulation 1995;92:2825-30.

8 Wu LL, Wu J, Hunt SJ, James BC, Vincent GM, Williams RR, et al. Plasma homocyst(e)ine as a risk factor for early familial coronary artery disease. Clin Chem 1994;40:552-61.

9 Graham I. Interactions between homocysteinemia and conventional risk factors in vascular disease. Eur Heart f 1994;15(suppl):530.

10 Mudd SH, Levy HL, Skovby F. Disorders of transsulphuration. In: Scriver CR, Beaudet AL Sly WS, Valle D, eds. The metabolic basis of inherited disease. 6th ed. Vol 1. New York: McGraw Hill, 1989: 693-734.

11 McCully KS, Wilson RB. Homocysteine theory of arteriosclerosis. Atherosclerosis 1975;22:21527.

12 Kang SS, Zhou J, Wong PWK, Kowalisyn J, Strokosch G. Intermediate homocysteinemia: a thermolabile variant of methylenetetrahydrofolate reductase. Am $\mathcal{g}$ Hum Genet 1988;43:41421 .

13 Engbersen AMT, Franken DG, Boers GHJ, Stevens EBM, Trijbels FJM, Blom HJ. Thermolabile 5,10-methylenetetrahydrofolate reductase as a cause of mild hyperhomocysteinemia. $\mathrm{Am}$ f Hum Genet 1995;56:142-50

14 Adams M, Smith PD, Martin D, Thompson JR, Lodwick D, Samani NJ. Genetic analysis of thermolabile methylenetetrahydrofolate reductase as a risk factor for myocardial infarction. $Q$ f Med 1996;89:437-44.

15 Wilcken DEL, Wang XI, Sim AS, McCredie M. Distribution in healthy and coronary populations of the methylenetetrahydrofolate reductase (MTHFR) $\mathrm{C}_{677} \mathrm{~T}$ mutation. Arterioscler Thromb Vasc Biol 1996;16:878-82.

16 Daly L, Robinson K, Tan KS, Graham IM. Hyperhomocysteinaemia: a metabolic risk factor for coronary heart disease determined by both genetic and environmental influences? $Q \mathcal{f} \mathrm{Med}$ 1993;86:685-9.

17 Jacques PF, Bostom AG, Williams RR, Ellison RC, Eckfeldt JH, Rosenberg IH, et al. Relation between folate status, a common mutation in methylenetetrahydrofolate reductase, and plasma homocysteine concentrations. Circulation 1996;93:7-9.

18 Selhub J, Jacques PF, Wilson PWF, Rush D, Rosenberg IH. Vitamin status and intake as primary determinants of homocysteinemia in an elderly population. 尹AMA 1993;270:2693-8.

19 Joosten E, van den Berg A, Reizler R, Naurath HJ, Lindenbaum J, Stabler SP, et al. Metabolic evidence that deficiencies of vitamin B-12 (cobalamin), folate, and vitamin B-6 occur commonly in elderly people. Am $\mathcal{C}$ Clin Nutr 1993;58:468-76.

20 Ueland PM, Refsum H, Brattstrom L. Plasma homocysteine and cardiovascular disease. In Francis RB, ed. Atherosclerotic cardiovascular disease, hemostasis and endothelial function. New York: Marcell Dekker, 1992: 183-235. 